\title{
Do social factors influence perceptions of the jaguar Panthera onca in Ecuador?
}

\author{
Hernán G. Álvarez and Galo Zapata-Ríos
}

\begin{abstract}
In Latin America, the jaguar Panthera onca is one of the most persecuted and hunted carnivores as a result of its depredation of livestock. In north-west Ecuador jaguar populations are highly threatened, and the largest known population (20-30 individuals) is in El Pambilar Wildlife Refuge, a wet tropical forest surrounded by degraded forests and an agricultural matrix. As the killing of jaguars is one of the main threats to this population, its conservation depends on the perceptions and behaviour of the people living in this region. We interviewed people from 159 households ( $64 \%$ of the total) in eight communities in the buffer zone of the Wildlife Refuge, to examine people's perceptions of any harm caused by jaguars, and to determine the factors that influence these perceptions. In general, people perceived that jaguars caused little harm to their domestic animals or to themselves. However, our models showed that young people with a low level of formal education are the demographic group most likely to hold negative attitudes towards the jaguar, suggesting this group could potentially benefit from involvement in environmental education and awareness programmes.
\end{abstract}

Keywords Conservation, Ecuador, Ecuadorian Chocó, El Pambilar Wildlife Refuge, human-wildlife interactions, jaguar, Panthera onca, psychological factors

Supplementary material for this article is available at doi.org/10.1017/So03060532000054X

\section{Introduction}

7 he killing of wildlife is one of the most widespread pro1 blems for species conservation (Dickman, 2010; Fisher, 2019). Often, the killing or injuring of species occurs in retaliation, or as a preventive measure, when the behaviour of animals, usually top predators or mega-herbivores, have a direct and recurring negative impact on the livelihoods and/or safety of people (Inskip \& Zimmermann, 2009; Cavalcanti et al., 2010; Grande et al., 2018; Marchini \& Macdonald, 2018). The persecution or killing of predators is generally assumed to be the direct result of attacks on domestic animals or livestock (Kansky et al., 2016). Under this

Hernán G. Álvarez (Corresponding author, (D) orcid.org/0000-0002-3431-0758) and Galo Zapata-Ríos Wildlife Conservation Society-Ecuador Program, Mariana de Jesús E7-248 y La Pradera, Quito, Ecuador

E-mail hg.alvarezb@gmail.com

Received 2 October 2019. Revision requested 9 December 2019.

Accepted 15 June 2020. First published online 18 October 2021. assumption, the obvious solution is the implementation of measures to reduce and/or avoid attacks, which is presumed to generate support for conservation from local people proportional to the effectiveness of the mitigation (Dickman, 2010; Kansky \& Knight, 2014).

In Latin America, jaguars Panthera onca are among the most persecuted and hunted carnivores as they often kill livestock and on rare occasions have attacked people (Neto et al., 2011; Iserson \& Francis, 2015; Jędrzejewski et al., 2017; Marchini \& Macdonald, 2018). Although mitigation techniques, such as installation of fences, use of guard dogs and financial compensation have been suggested as ways to reduce negative humanjaguar interactions (Stein et al., 2010; Cavalcanti et al., 2010, 2012; Bauer et al., 2017; Behmanesh et al., 2019), livestock loss is not the only factor driving intolerance of jaguars (Marchini \& Macdonald, 2012; Dickman et al., 2013; Kansky \& Knight, 2014). In the Amazon and Pantanal of Brazil, psychological and social factors such as attitudes, knowledge, socio-demographic variables, economics, and cultural conditions have influenced the killing of jaguars (Zimmermann et al., 2005; Marchini \& Macdonald, 2012, 2018; Porfirio et al., 2016). In Ecuador, there has been no examination of how people's perceptions influence jaguar conservation, even though jaguar populations are threatened by retaliatory killing, illegal trafficking of skin and fangs, reduction in their prey base, and habitat loss (Espinosa et al., 2016).

Historically, jaguar range in Ecuador included the Amazon and Coastal regions, but the population in the latter region requires urgent conservation attention because its range has been reduced by 90\% (Espinosa et al., 2016). In the Ecuadorian Chocó, in El Pambilar Wildlife Refuge and its surroundings, the jaguar population has been estimated to be $20-30$, the largest known population in the coastal region of Ecuador (Zapata-Ríos \& Araguillin, 2013). Some individual jaguars in this population have been recorded both inside and outside the protected area, which suggests they are crossing the highly degraded and fragmented matrix of secondary forests and agricultural areas (Zapata-Ríos \& Araguillin, 2013). In this situation there is a high probability of interactions between jaguars and local people involved in agriculture and livestock rearing, and the conservation of this jaguar population depends on the behaviour and perceptions of local communities. In this context, we examined local perceptions of harm caused by jaguars to domestic animals and people, and how socio-demographic variables, experience with jaguars, and knowledge about the jaguar influence these perceptions. 


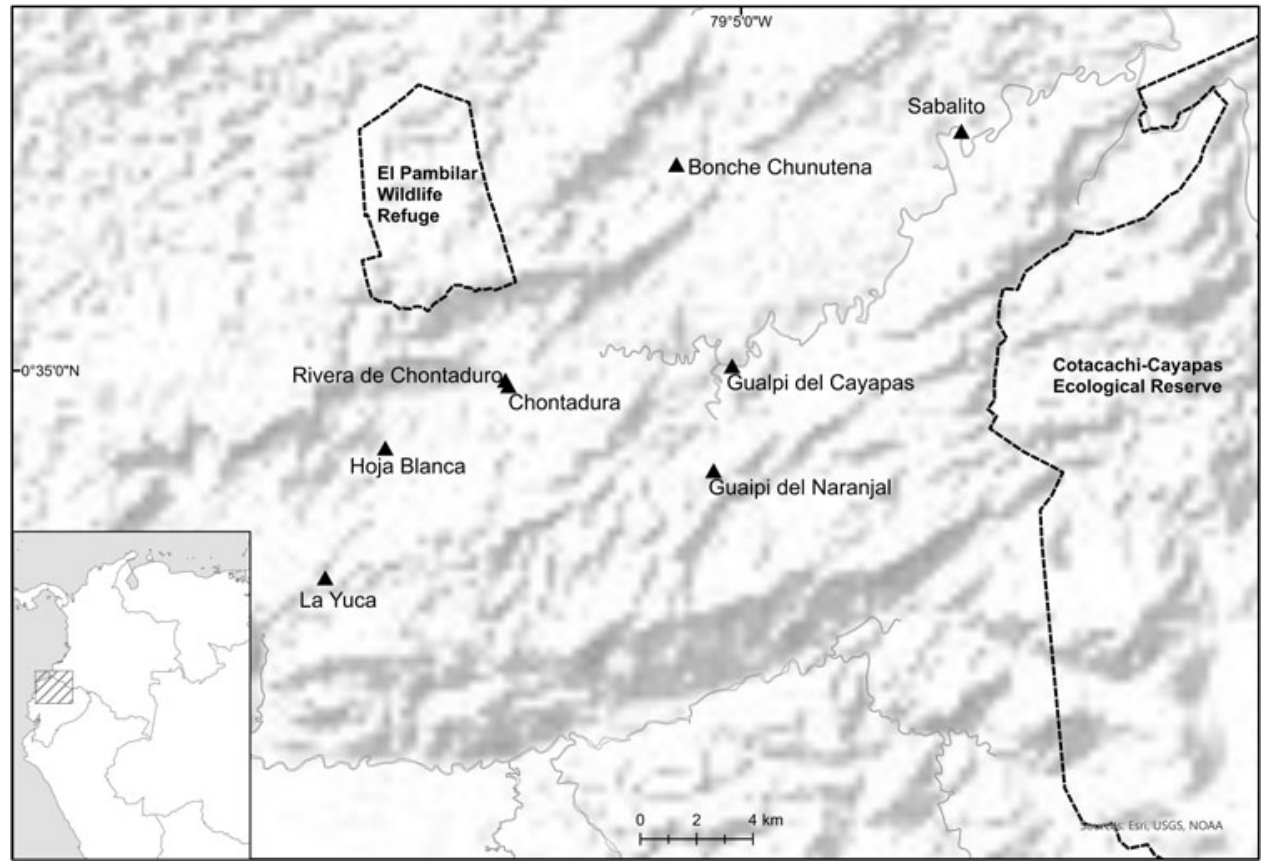

FIG. 1 The study area in north-west Ecuador, indicating the eight communities where we interviewed people, and El Pambilar Wildlife Refuge and Cotacachi-Cayapas Ecological Reserve.

\section{Study area}

We conducted the study in eight communities comprising both Indigenous and non-Indigenous people (La Yuca, Hoja Blanca, Riberas de Chontaduro, Chontaduro, Gualpí del Naranjal, Gualpí del Cayapas, Bonche Chunutena, and Sabalito). The study area is in the north-west wet tropical forest of Ecuador, known as the Chocó region, in the buffer area of two protected areas, El Pambilar Wildlife Refuge and Cotacachi-Cayapas Ecological Reserve (Fig. 1). The Ecuadorian Chocó lies within the Chocó-Darién ecoregion, a biodiversity hotspot, and is highly threatened (Myers et al., 2000; WWF, 2015). By 1996, the north-west tropical forest of Ecuador had been reduced by $>80 \%$ as a result of human population growth and associated colonization, logging and expansion of the agricultural frontier (López et al., 2003; Sierra et al., 2003; Zapata-Ríos \& Araguillin, 2013). The eight participating communities were selected based on two criteria: (1) previous participation in educational workshops concerning jaguar conservation, developed by the Ministry of Environment and using the Jaguars Forever educational curriculum (Wildlife Conservation Society, 2006), and (2) location within the buffer area of one of the two protected areas.

\section{Methods}

\section{Data collection}

During October 2017 we visited every household in the eight communities and interviewed the person available at the time of the visit, including adolescents (14-18 years old), adults and elders. Each interview was only in the presence of the person interviewed, using a questionnaire that contained 43 questions, including open-ended and close-ended questions. To ensure the questions were relevant to the local context, prior to data collection we piloted the questionnaire with five park rangers from El Pambilar Wildlife Refuge, whom we later trained to carry out the interviews. The rangers' comments were used to amend the questionnaire.

Questions covered four topics: socio-demographic variables, perceptions of people regarding jaguars, experience with jaguars, and knowledge about jaguars (Supplementary Material 1). The interviewers explained that the objective of the study was to understand the problems people have with jaguars, so as to find effective solutions, that the interviewee's identity would remain confidential, and that participation was voluntary. Interviews were in Spanish.

\section{Survey design}

We used two perception indices (Marchini \& Macdonald, 2018). The first was perception of the harm caused by jaguars to domestic animals, and the second the perception of harm caused by jaguars to people. Each index was based on four questions that examined perceptions in relation to past or future harm to the interviewee and other community members. Both indices were based on a sixpoint scale from no impact (o) to high impact (5) and were calculated by averaging each respondent's answers to the four questions.

To investigate factors that could potentially influence perceptions, we asked questions about (1) socio-demographics (age, gender, level of formal education, primary economic activity, property size, number of domestic animals owned 
by the household, time of residence in the community, number of people in the household), (2) experience with jaguars (number of domestic animals attacked by jaguars, number of people attacked by jaguars, number of encounters with jaguars), and (3) knowledge about jaguars (knowledge about jaguar natural history, whether the interviewee had participated in one of the jaguar conservation workshops implemented by the Ministry of Environment). For knowledge about the jaguar, we defined an index that was measured on a scale of o (not knowledgeable at all) to 1 (very knowledgeable) and that consisted of six questions.

To determine the reliability of each index (the two perception measures and level of knowledge about the jaguar), we calculated Cronbach's alpha (Cronbach \& Shavelson, 2004). On a scale of o to 1 , this coefficient evaluates the correlation between the questions, with values closer to 1 meaning the questions are more correlated and the index is more reliable (Cronbach \& Shavelson, 2004). The indices that had coefficients $\geq 0.70$ were considered acceptable and were used for statistical analysis (Vaske, 2008).

\section{Statistical analyses}

To determine perceptions of damage caused by jaguars to domestic animals and of threats to human safety, we calculated the mean and $95 \% \mathrm{CI}$ of the two perception indices. To investigate the influence of the three groups of explanatory variables (socio-demographics, experience with jaguars, and knowledge about jaguars) on perceptions, we evaluated the effect of each group on the two perception indices. For this, we used generalized linear mixed models (GLMM) using data only from those questionnaires that were complete $(n=135$ for the index of perception of harm to domestic animals and $n=129$ for the index of perception of harm to people). For each group of explanatory variables, we ran the models using all possible combinations (including the null model), ranked the models using the Akaike information criterion for small samples (AICc) and selected the variables included in the models that had a $\Delta \mathrm{AICc} \leq 2$. Finally, with all the variables selected for each group of variables, we ran all possible combinations (including the null model) and selected the best model that explained each index, based on $\triangle \mathrm{AICc} \leq 2$. As there was more than one model with $\mathrm{AICc} \leq 2$ for each perception index, we averaged the best models, and the variables whose confidence interval did not include zero were considered to have a strong evidence of having an effect on the perception indices (Doherty et al., 2012). As the social, cultural and economic conditions may not be the same in each of the eight communities, and because the interviewer was not the same in all communities, we included the community and interviewer as random variables in all models. To generate each index and calculate Cronbach's alpha we used SPSS 20 (IBM, Armonk, USA). We performed the GLMM in $R$ 3.3.1
(R Core Team, 2020), using the lme4 package (Bates et al., 2015). For the selection of models we used the MuMin package (Bartón, 2016) and for the figures we used the ggplot2 and visreg packages (Breheny \& Burchett, 2017).

\section{Results}

We interviewed 159 households (64\% of the total households in the eight communities). The perception indices indicated that people perceived jaguars caused low harm to their domestic animals (mean $0.43 \pm 95 \% \mathrm{CI} 0.30-0.57, \mathrm{n}=148$ ) and to people (mean $0.23 \pm 95 \% \mathrm{CI} 0.14-0.32, \mathrm{n}=148$ ).

Interviewees were $14-78$ years old (mean $38.14 \pm$ SD 14.96 years), $62 \%$ were men and $38 \%$ were women, they had resided in the communities for a mean of $16.32 \pm$ SD 12.00 years, $7 \%$ did not have any formal education, $21 \%$ had incomplete elementary school education, $30 \%$ had completed elementary school, $16 \%$ had incomplete high school education, $12 \%$ had completed high school, and $14 \%$ had college or higher level education. A mean of $4.99 \pm$ SD 2.91 people lived in each household, property sizes were $0-140 \mathrm{ha}$, and $70 \%$ of people were engaged in crop farming, $2 \%$ focused on livestock production, and $28 \%$ engaged in other primary economic activities (e.g. teaching, policing, business). Domestic animals were owned by $81 \%$ of households, with 1-106 animals per household, of which the majority were poultry (including chickens and ducks; 69\%), followed by cattle $(11 \%)$, dogs $(7 \%)$, pigs $(7 \%)$, horses $(3 \%)$, cats $(2 \%)$ and fish (1\%).

Eleven per cent of people (in five of the eight communities) reported attacks on their domestic animals, attributed to jaguars, during their residence in these communities. The majority of these incidents were reported from the communities of Hoja Blanca and Gualpí del Naranjal (Table 1). The animals reported to have been attacked were pigs, chickens and dogs (Table 1). In 53\% of these events people killed a jaguar, in $18 \%$ of the events people tried to kill a jaguar but failed, and in $29 \%$ of the events people did not do anything.

Five interviewees, three men and two women, from Hoja Blanca and Gualpí del Cayapas, mentioned nine unconfirmed events in which people were attacked by jaguars (Table 1). In all of these cases people had heard stories of the attacks, but did not know the victims personally. One of these events dated from 30 years previously. In total, $22 \%$ of interviewees reported 62 different encounters with jaguars. Bonche Chunutena was the only community where people had never seen a jaguar (Table 1 ). In the communities where people encountered jaguars, $61 \%$ of the time they did nothing, $21 \%$ of the time they ran away, in $9 \%$ of the encounters people killed the jaguar, and in the other $9 \%$ people tried to kill or scare it. Most people had little knowledge about the jaguar (mean knowledge index $0.33 \pm$ SD 0.23 ) 


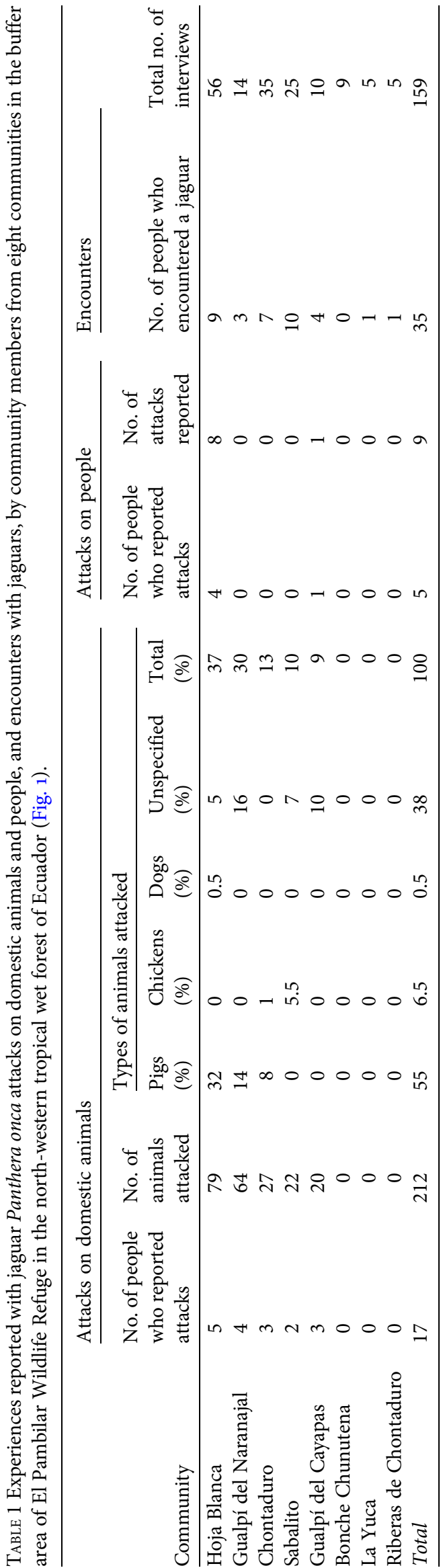

and only $20 \%$ of respondents had participated in an educational workshop for jaguar conservation.

There was more than one model $(\Delta \mathrm{AICc} \leq 2)$ that explained the index of perceived harm to domestic animals by the jaguar (Table 2). However, when averaging the best models, age (positively), and experience of attacks on domestic animals, of attacks on people, and with encounters (negatively) had a significant effect on people's perceptions. Number of domestic animals owned and level of formal education, which were also included in the best models, did not have a strong effect (Table 3, Fig. 2).

There was also more than one model $(\Delta \mathrm{AICc} \leq 2)$ that explained the index of perceived harm to people by jaguars (Table 2). When averaging the best models, the variables with the strongest negative effect were age and level of formal education, and property size did not have a significant effect (Table 3, Fig. 3).

\section{Discussion}

As far as we are aware, this is the first study to evaluate local perceptions of the harm caused by jaguars to people and their livelihoods in Ecuador. The majority of the local people interviewed perceived that the jaguar caused little harm to their domestic animals and themselves, and $74 \%$ of the interviewees had not had any direct experience with a jaguar. Although the majority of the people interviewed perceived jaguars caused little harm, in six of the eight communities 11 people $(7 \%)$ had apparently killed a total of $17 \mathrm{ja}-$ guars in the previous 20 years because they believed jaguars attacked their domestic animals. Our findings suggest that, even though most people in the communities did not perceive the jaguar to be a dangerous animal, the perception of a few people that jaguars cause harm is sufficient to be a threat to this species.

As we expected, our results showed that attacks on domestic animals were not the only predictors of perceptions of jaguars in the eight communities, in agreement with evidence from elsewhere (Zimmermann et al., 2005; Marchini \& Macdonald, 2012, 2018; Kansky et al., 2014). Age and level of formal education, along with experience of attacks and encountering jaguars, also shaped people's perceptions. Our results identified young people with little formal education, who are exposed to negative messages about large carnivores (possibly based on other people's experiences or anecdotal stories) as most likely to have negative perceptions of jaguars.

Although only a small per cent of the people we interviewed recounted bad experiences with jaguars (loss of domestic animals, knowledge of people attacked, and encounters), these beliefs were sufficiently strong to influence people's perception of the damage caused by jaguars to their domestic animals. We were not able to confirm the 
TABLE 2 Ranking of generalized linear mixed models (with $\Delta$ AICc $\leq 2$ ), and the null models, for the perception of harm caused by jaguars to domestic animals and people in eight communities in the Ecuadorian Chocó.

\begin{tabular}{lccc}
\hline Ranked models & & $\mathrm{AICc}^{2}$ & $\mathrm{AICw}^{4}$ \\
\hline Perception of harm to domestic animals & & & $\mathrm{K}^{5}$ \\
Age, Loss, Encounters, Attacks & 179.1 & 0.00 & 0.186 \\
Age, Loss, Encounters, Attacks, Education & 179.1 & 0.04 & 0.183 \\
Age, Loss, Encounters, Attacks, Animals & 180.4 & 1.29 & 0.098 \\
Age, Loss, Encounters, Attacks, Animals, Education & 180.9 & 1.82 & 0.075 \\
Null model & 264.4 & 85.31 & $5.58 \times 10^{-20}$ \\
Perception of harm to people & & & 0.320 \\
Age, Education & 215.5 & 0.00 & 0.198 \\
Age, Education, Property & 216.5 & 0.96 & 0.131 \\
Age & 217.3 & 1.78 & 4 \\
Null model & 222.3 & 6.72 & 0.011 \\
\hline
\end{tabular}

${ }^{1}$ Age, interviewee's age; Loss, experience with loss of domestic animals; Encounters, experience with jaguar encounters; Attacks, experience of people attacked; Education, level of formal education; Animals, number of domestic animals owned; Property, property size.

${ }^{2}$ Akaike information criterion for small samples.

${ }^{3}$ Difference in AICc from best-performing model.

${ }^{4}$ Model weight estimated from the AICc.

${ }^{5}$ Number of parameters in each model.

reported attacks, and some of the domestic animals reported to be involved were domestic fowl, which potentially suggests that jaguars may not have been involved. Other, smaller predators, such as the ocelot Leopardus pardalis and tayra Eira barbara, are more likely to attack small domestic animals (Amador-Alcalá et al., 2013; Tortato et al., 2013). People may blame the jaguar for predation by other predators (Conforti \& de Azevedo, 2003; Amit et al., 2013). The majority of respondents who reported knowing cases of people attacked by jaguars mentioned they had only heard stories about this, and in most of these cases the interviewees did not know the person who was attacked. Our results therefore suggest that positive predator identification and characterization of predatory events are needed to invalidate any myths and beliefs that local people may have about the jaguar (Amit et al., 2013; Hoogesteijn et al., 2016).

Surprisingly, none of the knowledge variables appeared to influence people's perceptions. This could be a result of the fact that, in general, the interviewees had little knowledge about jaguars and only a small per cent of the community members had participated in the environmental education workshops taught by the Ministry of Environment. Other studies have shown the importance of knowledge in reducing fear and increasing people's acceptance of jaguars (Cavalcanti et al., 2010; Engel et al., 2017). We therefore recommend to improve people's knowledge of the jaguar in these eight communities, and to increase participation in the educational workshops offered by the Ministry of Environment.

TABLE 3 Variables included in the averaging of the best generalized linear mixed models (with $\Delta$ AICc $\leq 2$ ) for the perception of harm caused by jaguars to domestic animals and people in eight communities in the Ecuadorian Chocó.

\begin{tabular}{lrr}
\hline Variables & Estimate \pm SE & $95 \%$ CI \\
\hline Perception of harm to domestic animals & & $0.198-0.665$ \\
Intercept & $0.431 \pm 0.119$ & $-0.012--0.003$ \\
Age $^{*}$ & $-0.007 \pm 0.002$ & $0.060-0.095$ \\
Experience with loss of domestic animals* $_{\text {Experience with people attacked }}^{*}$ & $0.078 \pm 0.009$ & $0.848-2.088$ \\
Experience with jaguar encounters & $1.468 \pm 0.316$ & $0.148-0.326$ \\
No. of domestic animals & $0.237 \pm 0.045$ & $-0.002-0.003$ \\
Level of formal education & $0.001 \pm 0.001$ & $-0.012-0.001$ \\
Perception of harm to people & $-0.005 \pm 0.003$ & \\
Intercept* & & $0.320-0.937$ \\
Age & & $-0.015--0.002$ \\
Level of formal education $^{*}$ & $0.628 \pm 0.157$ & $-0.024--0.001$ \\
Property size $^{*}$ & $-0.008 \pm 0.003$ & $-0.001-0.004$ \\
\hline
\end{tabular}

${ }^{*}$ Variables that had the strongest effect on people's perceptions. 
(a)

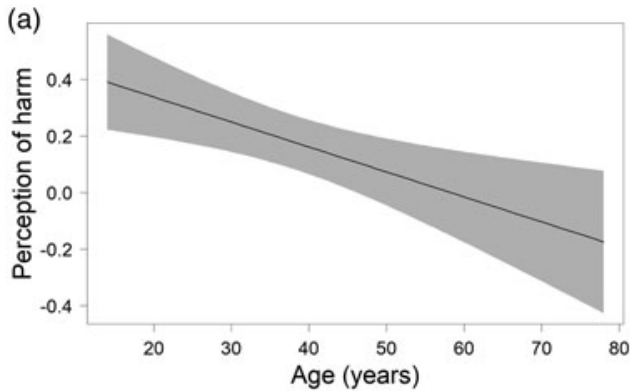

(c)

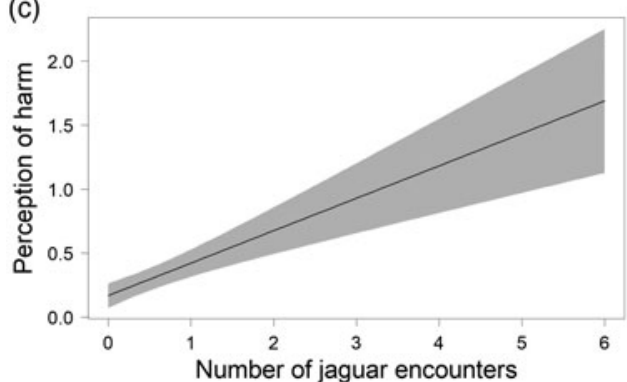

(b)

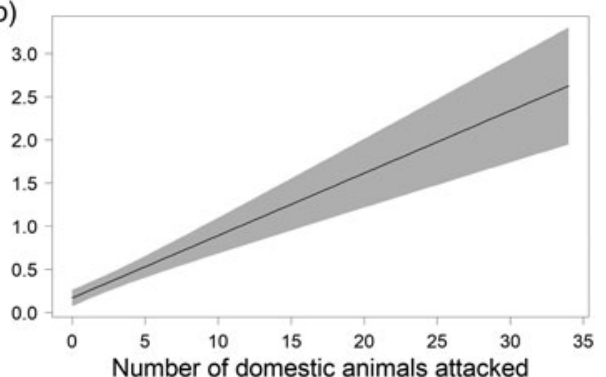

(d)

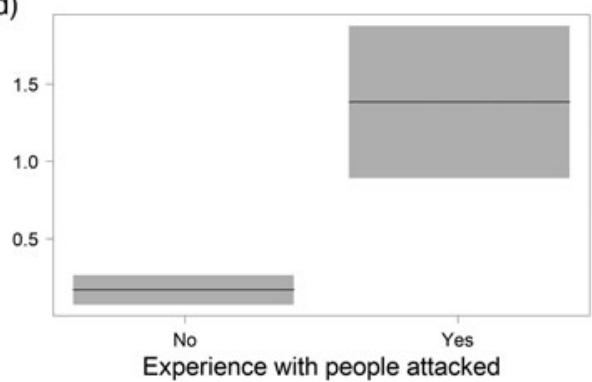

FIg. 2 Effect of (a) age,

(b) experience of attacks on domestic animals,

(c) experience of encounters with jaguars, and (d) experience of attacks on people on the perception of harm (on a six-point scale from 0 , no impact, to 5 , high impact) caused by the jaguar to domestic animals in eight communities of the Ecuadorian Chocó (Fig. 1). Gray area indicates 95\% CI. Note the different scales of the y-axes. (a)

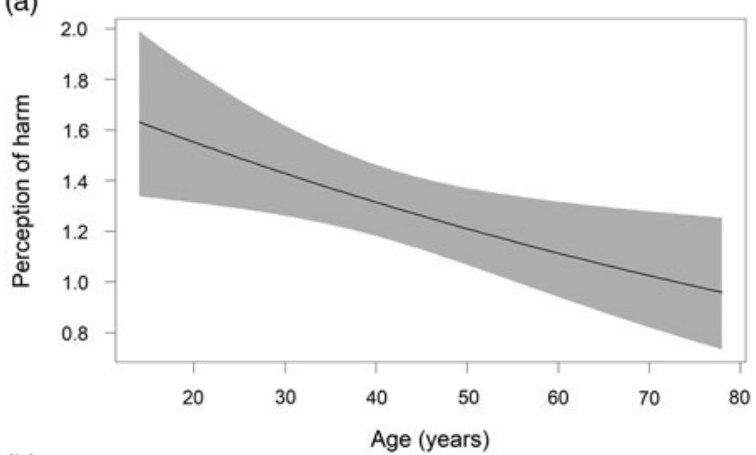

(b)

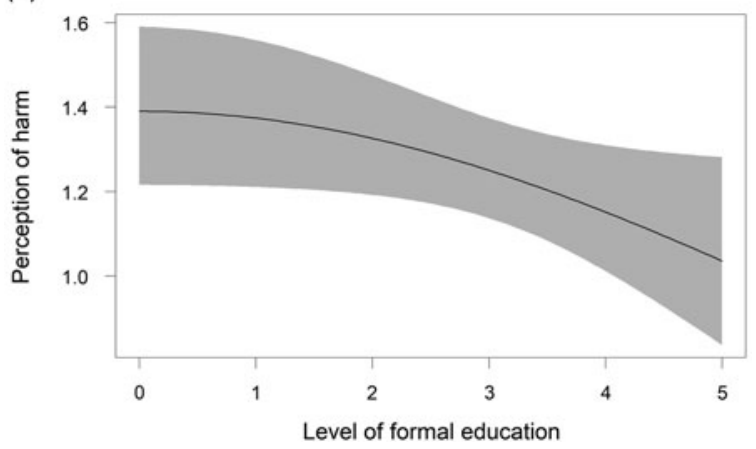

Fig. 3 Effect of (a) age, and (b) level of formal education (on a six-point scale: o, none; 1, incomplete elementary school; 2, complete elementary school; 3 , incomplete high school; 4, complete high school; 5 , university) on the perception of harm (on a six-point scale from o, no impact, to 5 , high impact) caused by the jaguar to people in eight communities in the Ecuadorian Chocó. Gray area indicates 95\% CI.

Note the different scales of the y-axes.

As human-dominated landscapes expand, the need to find innovative and effective solutions to mitigate the negative impacts of human-wildlife interactions is a conservation priority worldwide. Searching for solutions requires not only implementing technical measures that reduce attacks on domestic animals, but also understanding the human aspects of these events (Dickman, 2010; Redpath et al., 2015). Our results support evidence that social and psychological factors are important in shaping people's perceptions of large carnivores (Zimmermann et al., 2005; Inskip \& Zimmermann, 2009; Kansky \& Knight, 2014; Kansky et al., 2016; Marchini \& Macdonald, 2018), which in turn can contribute to the development of conservation approaches that target specific social groups. In the context of the eight communities where we carried out this research, young people with low levels of formal education are more likely to have negative perceptions of jaguars and are therefore a priority target group for conservation education. Finally, our results suggest that when people believe others have had bad experiences with jaguars, even if these experiences are few, this is sufficiently significant to influence people's perceptions. These beliefs, along with a low level of knowledge about jaguars, are a potential threat to the last viable population of jaguars in the Ecuadorian Chocó.

Acknowledgements We thank the local people of the eight participating communities for their time and willingness to share their knowledge and views; the park rangers of El Pambilar Wildlife Refuge for their collaboration; Maria Eugenia Iezzi for help with data analysis; and the project Advancing Landscape Approaches in Ecuador's National Protected Area System to Improve Conservation of Globally Endangered Wildlife (Project ID 00086648) of the Ministry of Environment of Ecuador, funded by the Global Environmental Facility, United Nations Development Programme and Wildlife Conservation Society.

Author contributions Study design, training park rangers: HGA, GZ-R; data analysis: HGA; writing: HGA, GZ-R. 


\section{Conflicts of interest None.}

Ethical standards This research followed the ethical guidelines developed by the British Sociological Association, and otherwise abided by the Oryx guidelines on ethical standards. The questionnaire respected local rights and beliefs, and economic and cultural interests. We obtained free, prior and informed consent from all the people included in this study, and guaranteed their anonymity.

\section{References}

Amador-Alcalá, S., Naranjo, E.J. \& Jiménez-Ferrer, G. (2013) Wildlife predation on livestock and poultry: implications for predator conservation in the rainforest of south-east Mexico. Oryx, 47, 243-250.

Amit, R., Gordillo-Chávez, E.J. \& Bone, R. (2013) Jaguar and puma attacks on livestock in Costa Rica. Human-Wildlife Interactions, 7, 77-84.

B ARtón, K. (2016) MuMIn: Multi-Model Inference. R package version 1.15.6. cran.r-project.org/web/packages/MuMIn/index.html [accessed 25 June 2018].

Bates, D., Mächler, M., Bolker, B. \& Walker, S. (2015) Fitting linear mixed-effects models using lme4. Journal of Statistical Software, 67, 1-48.

Bauer, H., Múller, L., van der Goes, D. \& Sillero-Zubiri, C. (2017) Financial compensation for damage to livestock by lions Panthera leo on community rangelands in Kenya. Oryx, 51, 106-114.

Behmanesh, M., Malekian, M., Hemami, M.R. \& Fakheran, S. (2019) Patterns and determinants of human-carnivore conflicts in central Iran: realities and perceptions behind the conflict. Human Dimensions of Wildlife, 24, 14-30.

Breheny, P. \& Burchett, W. (2017) Visualization of regression models using visreg. The R Journal, 9, 1-17.

Cavalcanti, S.M.C., Crawshaw, P.G. \& Tortato, F.R. (2012) Use of electric fencing and associated measures as deterrents to jaguar predation on cattle in the Pantanal of Brazil. In Fencing for Conservation: Restriction for Evolutionary Potential or a Riposte to Threatening Processes? (eds M. Somers \& M. Hayward), pp. 295-309. Springer, New York, USA.

Cavalcanti, S.M.C., Marchini, S., Zimmermann, A., Gese, E.M. \& Macdonald, D.W. (2010) Jaguars, livestock, and people in Brazil: realities and perceptions behind the conflict. In The Biology and Conservation of Wild Felids (eds D. Macdonald \& A. Loveridge), pp. 383-402. Oxford University Press, Oxford, UK.

Conforti, V.A. \& de Azevedo, F.C.C. (2003) Local perceptions of jaguars (Panthera onca) and pumas (Puma concolor) in the Iguazu National Park area, south Brazil. Biological Conservation, $111,215-221$.

Cronbach, L. \& Shavelson, R.J. (2004) My current thoughts on coefficient alpha and successor procedures. Educational and Psychological Measurement, 64, 391-418.

Dickman, A.J. (2010) Complexities of conflict: the importance of considering social factors for effectively resolving human-wildlife conflict. Animal Conservation, 13, 458-466.

Dickman, A., Marchini, S. \& Manfredo, M. (2013) The human dimension in addressing conflict with large carnivores. Key Topics in Conservation Biology, 2, 110-126.

Doherty, P., White, G. \& Burnham, K. (2012) Comparison of model building and selection strategies. Journal of Ornithology, $152,317-323$.

Engel, M.T., Vaske, J.J., Marchini, S. \& Bath, A.J. (2017) Knowledge about big cats matters: insights for conservationists and managers. Wildlife Society Bulletin, 41, 398-404.
Espinosa, S., Albuja, L., Tirira, D., Zapata-Ríos, G., Araguillin, E., Utreras, V. \& Noss, A. (2016) Análisis del estado de conservación del jaguar en el Ecuador. In El Jaguar en el Siglo XXI: La Perspectiva Continental (eds R.A. Medellin, J.A. de la Torre, H. Zarza, C. Chávez \& G. Ceballos), pp. 320-339. Ediciones Científicas Universitarias, Universidad Nacional Autonoma de México, Mexico City, Mexico.

Fisher, M. (2019) Whose conflict is it anyway? Mobilizing research to save lives. Oryx, 50, 377-378.

Grande, J.M., Zuluaga, S. \& Marchini, S. (2018) Casualties of human-wildlife conflict. Science, 360, 1309.

Hoogesteijn, R., Hoogesteijn, A., Tortato, F., Payan, E., Jedrzejewski, W., Marchini, S. et al. (2016) Consideraciones sobre la peligrosidad del jaguar para los humanos: ¿quién es letal para quién? In Conflictos entre Felinos y Humanos en America Latina (eds C. Castaño-Uribe, C.A. Lasso, R. Hoogesteijn, A. Diaz-Pulido \& E. Payán), pp. 445-466. Instituto de Investigación de Recursos Biológicos Alexander von Humboldt, Fundación Herencia Ambiental Caribe and Panthera, Bogotá, Colombia.

Inskip, C. \& ZimmermanN, A. (2009) Human-felid conflict: a review of patterns and priorities worldwide. Oryx, 43, 18-34.

IsERSON, K.V. \& Francis, A.M. (2015) Jaguar attack on a child: case report and literature review. Western Journal of Emergency Medicine, 16, 303-309.

Jędrzejewski, W., Carreño, R., Sánchez-Mercado, A., Schmidt, K., Abarca, M., Robinson, H.S. et al. (2017) Human-jaguar conflicts and the relative importance of retaliatory killing and hunting for jaguar (Panthera onca) populations in Venezuela. Biological Conservation, 209, 524-532.

Kansky, R., Kidd, M. \& Knight, A.T. (2014) Meta-analysis of attitudes toward damage-causing mammalian wildlife. Conservation Biology, 28, 924-938.

Kansky, R., Kidd, M. \& Knight, A.T. (2016) A wildlife tolerance model and case study for understanding human-wildlife conflicts. Biological Conservation, 201, 137-145.

Kansky, R. \& Knight, A.T. (2014) Key factors driving attitudes towards large mammals in conflict with humans. Biological Conservation, 179, 93-105.

López, S., Sierra, R. \& Tirado, M. (2003) Tropical deforestation in the Ecuadorian Chocó: logging practices and socio-spatial relationships. Professional Geographer, 55, 477-490.

Marchini, S. \& Macdonald, D.W. (2012) Predicting ranchers' intention to kill jaguars: case studies in Amazonia and Pantanal. Biological Conservation, 147, 213-221.

Marchini, S. \& Macdonald, D.W. (2018) Mind over matter: perceptions behind the impact of jaguars on human livelihoods. Biological Conservation, 224, 230-237.

Myers, N., Mittermeier, R., Mittermeier, C., Da Fonseca, G. \& Kent, J. (2000) Biodiversity hotspots for conservation priorities. Nature, 403, 853-858.

Neto, M.F.C., Garrone Neto, D. \& Haddad, V. (2011) Attacks by jaguars (Panthera onca) on humans in central Brazil: report of three cases, with observation of a death. Wilderness and Environmental Medicine, 22, 130-135.

Porfirio, G., Sarmento, P., Leal, S. \& Fonseca, C. (2016) How is the jaguar Panthera onca perceived by local communities along the Paraguai River in the Brazilian Pantanal? Oryx, 50, 163-168.

R Core Team (2020) R: A Language and Environment for Statistical Computing. R Foundation for Statistical Computing, Vienna, Austria. R-project.org [accessed 25 June 2018].

Redpath, S.M., Bhatia, S. \& Young, J. (2015) Tilting at wildlife: reconsidering human-wildlife conflict. Oryx, 49, 222-225.

Sierra, R., Tirado, M. \& Palacios, W. (2003) Forest-cover change from labor- and capital-intensive commercial logging in the 
Southern Choco Rainforests. The Professional Geographer, 55, 477-490.

Stein, A.B., Fuller, T.K., Damery, D.T., Sievert, L. \& Marker, L.L. (2010) Farm management and economic analyses of leopard conservation in north-central Namibia. Animal Conservation, 13, 419-427.

Tortato, F.R., Tortato, M.A. \& Koenler, E. (2013) Poultry predation by Leopardus wiedii and Leopardus tigrinus (Carnivora: Felidae) in southern Brazil. Latin American Journal of Conservation, 3, 51-53.

VASKe, J.J. (2008) Survey Research and Analysis: Applications in Parks, Recreation and Human Dimensions. Venture Publishing, State College, USA.
Wildlife Conservation Society (2006) Jaguares para Siempre: Herramientas Educativas para Salvar al Gato más Grande de las Américas. Wildlife Conservation Society, New York, USA.

WWF (2015) Living Forests Report: Chapter 5. WWF, Gland, Switzerland. worldwildlife.org/publications/living-forests-reportchapter-5-saving-forests-at-risk [accessed 29 June 2021].

Zapata-Ríos, G. \& Araguillin, E. (2013) Estado de conservación del jaguar y el pecarí de labio blanco en el Ecuador occidental. Review Biodiversity Neotropical, 3, 21-29.

Zimmermann, A., Walpole, M.J. \& Leader-Williams, N. (2005) Cattle ranchers' attitudes to conflicts with jaguar Panthera onca in the Pantanal of Brazil. Oryx, 39, 406-412. 